\title{
Failure of Chlamydia trachomatis to pass transplacentally to fetuses of TO mice infected during pregnancy
}

\author{
MAUREEN TUFFREY, P. FALDER, J. GALE* and D. TAYLOR-ROBINSON
}

Division of Sexually Transmitted Diseases, MRC Clinical Research Centre, Watford Road, Harrow, Middlesex HA1 3UJ

\begin{abstract}
Summary. Mice (strain TO) were inoculated with a human strain of Chlamydia trachomatis (serovar E) either 14 days before the detection of a vaginal plug (day 1 of pregnancy), or from one to nine days thereafter. The organisms were given via the intraperitoneal route (ip) or intravenously with an additional intravaginal inoculum (iv + ivag). Mice were killed on day 18 of pregnancy and the contents of the uterus examined. Chlamydiae were isolated from at least one placental disk of about a quarter of the mice. Organisms given via the ip route established placental colonisation more effectively. Thus, placental colonisation was detected in five of 16 mice given chlamydiae by the ip route (in six of eight placentas in one mouse), whereas colonisation occurred in only a single placenta from one of nine mice infected via the iv + ivag routes. Chlamydiae were isolated from $13(6 \cdot 25 \%)$ of 208 placentas examined; the degree of colonisation was variable and the individual placentas were colonised independently. Chlamydiae were not recovered from fetal tissue, even when there was heavy placental colonisation. Nor were they isolated from maternal spleens, even though there was antibody to $C$. trachomatis in all maternal sera; the titres were in the range 4-2048, depending on the time of chlamydial challenge. These experiments show that $C$. trachomatis did not cross the placenta and that the pregnancy outcome in these mice was not affected.
\end{abstract}

\section{Introduction}

Chlamydia psittaci causes placental infection and abortion in various mammals, particularly cattle and sheep (Storz, 1971). Acute placentitis and spontaneous abortion in a woman caused by $C$. psittaci of sheep origin has also been described (Wong et al., 1985). The organisms were isolated from the placenta and fetal tissues, and chlamydial antibodies were found in the maternal serum. However, the effect of $C$. trachomatis (chlamydiae) on the outcome of pregnancy is still speculative. Schachter (1967) isolated chlamydiae from the products of human abortion, but it was uncertain whether this could be attributed to contamination during passage through an infected birth canal. Martin et al. (1982) reported that stillbirth or

Received 11 Dec. 1986; accepted 9 Jan. 1987.

* J. Gale was a visiting scientist from the Department of Epidemiology, School of Public Health and Community Medicine, University of Washington, Seattle, Washington, U.S.A. neonatal death was ten times more common in women infected with $C$. trachomatis than in uninfected women. In contrast, several other workers have reported that cervical infection with C. trachomatis did not predict spontaneous abortion, stillbirth, prematurity or premature rupture of membranes (Heggie et al., 1981; Harrison et al., 1983; Munday et al., 1984). However, in one of these investigations (Harrison et al., 1983), the small subgroup of women who had IgM-positive $C$. trachomatis infections were delivered of more lowbirthweight infants and had a greater risk of preterm delivery. Nevertheless, IgM chlamydial antibody was not detected in any of the cord blood samples from these women indicating that the fetuses were not infected congenitally.

To investigate further the effect of $C$. trachomatis on the outcome of pregnancy, we used a mouse model of chlamydial genital-tract infection. The failure of $C$. trachomatis infection to affect implantation, placentation, litter size or birthweight, or to induce fetal deaths and abnormalities in the mouse has been described previously (Gale et al., 1986). 
In this communication we describe our attempts to ascertain whether $C$. trachomatis crosses the placental barrier and colonises the fetuses in utero.

\section{Materials and methods}

\section{Mice}

TO mice, 7-10 weeks old, were bred and maintained in the specific pathogen-free unit at the Clinical Research Centre; they had not been used for breeding experiments previously. One male was boxed with four females which were examined daily for the presence of a vaginal plug that signified successful mating. Plugged females were removed immediately to a separate box with the date of the first observation of the vaginal plug being taken as the first day of pregnancy.

\section{C. trachomatis strain}

A strain of serovar E, designated N.I.1, was used. It had been isolated from the endocervix of a contact of a man with non-gonococcal urethritis and was passaged serially in McCoy cells. For the inocula, chlamydiae from the ninth passage were suspended in sucrose phosphate medium (2SP) containing fetal calf serum $10 \%$ and stored in liquid nitrogen. This chlamydial suspension was mycoplasma free, contained $2 \times 10^{7}$ inclusion-forming units (ifu)/ml, and was known to cause salpingitis in mice (Tuffrey et al., 1986).

\section{Inoculation of mice}

Groups of mice were inoculated with chlamydiae at various intervals before or after finding vaginal plugs. In the first experiment, mice were inoculated intraperitoneally (ip) with $2 \times 10^{6}$ ifu of chlamydiae or $2 \mathrm{SP}$ alone. Two mice were challenged ip with N.I.1 14 days before the detection of a vaginal plug and a total of 16 mice were inoculated from day 1 to day 9 of gestation. Four mice serving as controls were inoculated ip, in pairs, with 2SP alone on days 6 and 9 after detection of plugs. In the second experiment, mice were inoculated with $2 \times 10^{6}$ ifu intravenously (iv) and with $1 \times 10^{6}$ ifu intravaginally (ivag). Nine mice were inoculated with chlamydiae on days 2-6 of gestation, and eight mice, serving as controls, received $2 \mathrm{SP}$ alone on days 4 and 6.

\section{Necropsy}

Mice killed by inhaled anaesthetic on day 18 of pregnancy were opened aseptically through a ventral abdominal incision. Blood was withdrawn from the heart and the contents of the abdominal cavity examined carefully. The uterus was opened and fetal viability, macroscopic 'resorptions', and the anatomical sites of all implantations were recorded. Classification of embryonic death into early, middle and late was estimated according to the criteria of McLaren and Michie (1959). Live fetuses were examined for gross abnormalities and weighed individually. Then they were killed and the fetal livers dissected out and each homogenised in $1 \mathrm{ml}$ of $2 \mathrm{SP}$ by repeated withdrawal into a sterile 1 -ml disposable syringe. The remainder of each fetus was minced with sterile scissors in $1 \mathrm{ml}$ of $2 \mathrm{SP}$. Placental disks were dissected from fetuses and membranes and individually homogenised with $1 \mathrm{ml}$ of $2 \mathrm{SP}$ by use of a $1-\mathrm{ml}$ syringe. Finally, maternal spleens were homogenised in the same way. All samples were stored in liquid nitrogen until required for isolation procedures.

\section{Isolation of chlamydiae}

To estimate any toxic effects that the tissue samples might have on McCoy-cell monolayers, and the optimum conditions for avoiding them, a pilot experiment was undertaken with strain N.I.1 and various treatments and dilutions of normal placental and fetal homogenates. Liver was less inhibitory to chlamydial isolation than placental disks, but the following schedule was found to be optimal for both and was used throughout the study. Spleen, liver and placental tissues were thawed rapidly and agitated on a vortex mixer for $30 \mathrm{~s}$. Samples were then added to $6 \mathrm{ml}$ of complete medium containing glucose and antibiotics (CMGA) at $37^{\circ} \mathrm{C}$ in a sterile conical-bottomed glass tube. The tubes were centrifuged at $1200 \mathrm{rpm}$ for $10 \mathrm{~min}, 1 \mathrm{ml}$ samples of the supernate were seeded on to six cycloheximide-treated McCoy-cell monolayers for isolation of chlamydiae as described previously (Thomas et al., 1977). The cell monolayers were stained by Giemsa reagent and examined by darkfield microscopy. The whole fetuses were treated in the same way, except that the samples of minced tissue were homogenised in a glass grinder before adding to CMGA.

\section{Detection of antibody}

The titre of IgG antibody to $C$. trachomatis in the serum of individual mice on day 18 of pregnancy was measured by a micro-immunofluorescence technique with a fluorescein-labelled rabbit anti-mouse IgG conjugate (Thomas et al., 1976).

\section{Results}

Placental colonisation with strain N.I.1 in mice inoculated during pregnancy is shown in table I. Chlamydiae were isolated from at least one placental disk of about one quarter of the mice inoculated with strain N.I.1. Placental colonisation occurred in 5 of 16 mice inoculated ip and chlamydiae were isolated from 6 of 8 placental disks of one mouse. In contrast, placentas were colonised in only 1 of 9 mice inoculated via the combined iv and ivag routes, and in this animal a single placenta only was colonised. Thus, challenge via the ip route was the more effective in establishing placental coloni- 
Table 1. Placental colonisation of TO mice inoculated with strain N.I.1 during pregnancy

\begin{tabular}{lccc}
\hline $\begin{array}{l}\text { Route and time* of } \\
\text { inoculation }\end{array}$ & $\begin{array}{c}\text { Number of mice colonised placentally/ } \\
\text { Number inoculated (\%) }\end{array}$ & $\begin{array}{c}\text { Number of } \\
\text { placentas examined }\end{array}$ & $\begin{array}{c}\text { Number (\%) of } \\
\text { placentas colonised }\end{array}$ \\
\hline $\begin{array}{l}\text { ip days 1-9 } \\
\text { iv + ivag days 2-6 }\end{array}$ & $5 / 16(31 \%)$ & 131 & $12(9 \%)$ \\
$1 / 9(11 \%)$ & 77 & $1.3 \%)$ \\
\hline
\end{tabular}

* Presence of a vaginal plug $=$ day 1.

ip $=$ intraperitoneal, iv $+\mathrm{ivag}=$ intravenous + intra-vaginal.

sation. Overall, chlamydiae were isolated from 13 $(6 \cdot 25 \%)$ of the 208 placentas examined.

The degree of colonisation, assessed by the number of chlamydial inclusions in McCoy-cell monolayers, varied; the range was from a few ifu/ monolayer to many hundreds (table II). Furthermore, the placentas were colonised as independent units. Thus, although the placental disks nearest the oviduct (L1, R1 in table II) most of ten harboured the organisms in mice inoculated by the ip route, this was not always the case. Disks in positions R3 and R4 were colonised in mouse no. 15 , but not those in positions $\mathrm{R} 1$ and $\mathrm{R} 2$. In mouse no. 26, which was inoculated by iv and ivag routes, the only placenta colonised was in position $\mathrm{R} 8$, the one nearest to the cervix.

The results of attempts to isolate chlamydiae from fetal tissue are shown in table III. Chlamydiae were not recovered even when there was heavy placental colonisation. Nor were they isolated from maternal spleens, even though there was antibody to $C$. trachomatis in all maternal sera, with titres in the range 4-2048, depending on the time of chlamydial challenge. The mice were killed on day 18 of pregnancy: therefore, the time allowed for the development of an antibody response was 9-18 days.

Placental colonisation was not seen when mice were challenged before the fifth day of pregnancy (table III). Although the number of mice inoculated with chlamydiae during this time was small, 61 placental disks were examined. Furthermore, there was no evidence of colonisation in any of 15 placentas from two mice that were given chlamydiae, ip, 14 days before the detection of a vaginal plug. Both of these mice had a chlamydial serum antibody titre of 2048 , but chlamydiae were not recovered from their spleens.

\section{Discussion}

Challenging mice via the ip route with $C$. trachomatis was more effective in bringing about placental colonisation than challenging them via the iv and ivag routes. The ip route has also been found to be the most effective in causing colonisa-

Table II. Position in uterus of colonised placentas

\begin{tabular}{|c|c|c|c|c|c|}
\hline Mouse no. & $\begin{array}{l}\text { Route of } \\
\text { inoculation }\end{array}$ & $\begin{array}{c}\text { Day of } \\
\text { inoculation }\end{array}$ & $\begin{array}{l}\text { Number of } \\
\text { fetuses }\end{array}$ & $\begin{array}{l}\text { Position of colonised } \\
\text { placenta(s) }\end{array}$ & $\begin{array}{c}\text { Number of ifu/ } \\
\text { monolayer }\end{array}$ \\
\hline 7 & ip & 5 & $4 \mathrm{~L} \quad 6 \mathrm{R}$ & $\begin{array}{l}\text { L1 } \\
\text { L2 }\end{array}$ & $\begin{array}{r}>100 \\
5\end{array}$ \\
\hline 1 & ip & 6 & $2 \mathrm{~L} \quad 2 \mathrm{R}$ & $\mathrm{R} 1$ & 3 \\
\hline 3 & ip & 6 & $4 \mathrm{~L} \quad 6 \mathrm{R}$ & L1 & 10 \\
\hline 13 & ip & 9 & $5 \mathrm{~L} \quad 3 \mathrm{R}$ & $\begin{array}{l}\text { L1 } \\
\text { R1 }\end{array}$ & $\begin{array}{l}2 \\
2\end{array}$ \\
\hline 15 & ip & 9 & $4 \mathrm{~L} \quad 4 \mathrm{R}$ & $\begin{array}{l}\text { L1 } \\
\text { L2 } \\
\text { L3 } \\
\text { L4 } \\
\text { R3 } \\
\text { R4 }\end{array}$ & $\begin{array}{r}42 \\
>100 \\
>100 \\
>100 \\
2 \\
6\end{array}$ \\
\hline 26 & iv + ivag & 6 & $8 \mathrm{~L} \quad 3 \mathrm{R}$ & R8 & $>100$ \\
\hline
\end{tabular}

$\mathrm{L} 1=$ Left uterine horn nearest oviduct; $\mathrm{R} 1=$ right uterine horn nearest oviduct; etc. 
Table III. Recovery of strain N.I.1 from the placentas and fetuses of TO mice inoculated with chlamydiae before or during pregnancy

\begin{tabular}{lccccc}
\hline $\begin{array}{c}\text { Route of } \\
\text { inoculation }\end{array}$ & $\begin{array}{c}\text { Day of challenge (vaginal } \\
\text { plug = day 1) }\end{array}$ & $\begin{array}{c}\text { Number of mice colonised } \\
\text { placentally/number challenged }\end{array}$ & $\begin{array}{c}\text { Number of } \\
\text { placentas } \\
\text { examined }\end{array}$ & $\begin{array}{c}\text { Number of } \\
\text { placentas } \\
\text { colonised }\end{array}$ & $\begin{array}{c}\text { Number of } \\
\text { fetuses } \\
\text { colonised }\end{array}$ \\
\hline ip & -14 & $0 / 2$ & 15 & 0 & 0 \\
ip & 1 & $0 / 1$ & 6 & 0 & 0 \\
& 2 & $0 / 1$ & 11 & 0 & 0 \\
& 3 & $0 / 1$ & 6 & 0 & 0 \\
& 5 & $1 / 1$ & 10 & 2 & 0 \\
iv & 6 & $2 / 5$ & 16 & 2 & 0 \\
& 8 & $0 / 2$ & 44 & 0 & 0 \\
& 9 & $2 / 5$ & 9 & 0 & 0 \\
& 2 & $0 / 1$ & 8 & 0 & 0 \\
& 3 & $0 / 1$ & 21 & 0 & 0 \\
& 4 & $0 / 3$ & 12 & 0 & 0 \\
\end{tabular}

tion of mouse placentas with other micro-organisms. When given this way, intestinal as well as abortive strains of ovine C.psittaci killed infant mice in utero (Buzoni-Gatel and Rodolakis, 1983) and two mutant strains of ovine $C$. psittaci, the virulence of which was attenuated for pregnant mice, colonised the placenta and induced intrauterine death (Rodolakis, 1983). The ip route was also the most effective way of colonising mouse placentas with Brucella abortus (Bosseray, 1980). Partial colonisation was observed in $25 \%$ of mice, and the probability of colonisation was the same for all sites of implantation. Because the mouse ovary is almost completely enveloped by a bursa, it is extremely unlikely that organisms given ip could reach the uterus via the oviducts and, therefore, preferentially colonise the sites nearest the ovary. Indeed, ip inoculation with chlamydiae does not result in salpingitis in the mouse model, and organisms cannot be recovered subsequently from the genital tract (Tuffrey et al., 1986). Placental colonisation must be the result of haematogenous spread of the organisms, despite our inability to detect chlamydiae in the maternal spleens. Organisms given ip reach the blood stream after lymphatic carriage which may allow their multiplication and thus provide a greater chance of colonisation. C. trachomatis can grow to a limited extent in mouse peritoneal macrophages (Kuo, 1978), but it is thought that non-lymphogranuloma venereum (LGV) serovars multiply only in epithelial cells whereas LGV serovars infect both epithelial and lymphoid tissue (Kunimoto and Brunham, 1985). This hypothesis is consistent with our ability to isolate strain $\mathrm{SA}_{2} \mathrm{f}$ (an L2 serovar) from the spleens of mice inoculated by the iv route (Tuffrey et al., 1984) and our failure to recover strain N.I.1 in the current experiments. Manor and Sarov (1986) found that infection with $C$. trachomatis was abortive in human monocytes and productive only in monocyte-derived macrophages with an LGV serovar. In contrast, Rothermel (1985) showed that blood monocytes and monocyte-derived macrophages were equally susceptible to $C$. psittaci. It is interesting to note that the histological pattern of the $C$. psittaci-induced placentitis described by Wong et al. (1985) suggested that the infection spread haematogenously to the placenta, rather than ascending from the cervix. The ability of $C$. psittaci to cross the placental barrier may be due to its facility to replicate more easily and in more cell types than C. trachomatis.

Previous experiments in mice have shown that pre-treatment with progesterone and surgical inoculation of organisms directly into the uterus is the most effective way of producing chlamydial infection of the genital tract (Tuffrey and TaylorRobinson, 1981). Because this schedule was unsuitable for the current experiments, we chose to give some of the mice additional ivag inocula in an attempt to provide a closer contact of organisms with the genital tract. There was, however, no evidence that these organisms colonised the genital tract. It is clear from the results of these experiments that $C$. trachomatis did not cross the mouse placental barrier to colonise the fetus even when there were large numbers of organisms in the placenta. This was not a spurious failure due to technical inadequacy of isolating chlamydiae from the fetus because they were found in 13 of 208 placentas 
tested and placental tissue was more inhibitory than fetal tissue for chlamydial isolation. As $C$. trachomatis organisms did not cross the placental barrier, it is not surprising that they failed to affect the outcome of pregnancy (Gale et al., 1986). However, it is possible that if the organisms somehow gain access to the uterus before or during pregnancy they may still have a deleterious effect on murine and human embryos. This may be tested in further experiments with the mouse model.

In experiments conducted up to now mice have been inoculated from the first to the ninth day of gestation. This period, up to and during placentation, was chosen because it was the one during

\section{REFERENCES}

Bosseray N 1980 Colonization of mouse placentas by Brucella abortus inoculated during pregnancy. British Journal of Experimental Pathology $61: 361-368$.

Buzoni-Gatel D, Rodolakis A 1983 A mouse model to compare virulence of abortive and intestinal ovine strains of Chlamydia psittaci: influence of the route of inoculation. Annales de Microbiologie (Institut Pasteur) 134A:91-99.

Gale J L, Tuffrey M, Falder P, Taylor-Robinson D 1986 Fetal outcomes in mice infected with Chlamydia trachomatis. In: Oriel D et al. (eds) Chlamydial Infections. Cambridge University Press, pp 384-387.

Harrison H R, Alexander E R, Weinstein L, Lewis M, Nash M, Sim D A 1983 Cervical Chlamydia trachomatis and mycoplasmal infections in pregnancy: epidemiology and outcomes Journal of the American Medical Association 250: $1721-1727$.

Heggie A D, Lumicao G G, Stuart L A, Gyves M T 1981 Chlamydia trachomatis infection in mothers and infants. American Journal of Diseases of Children 135:507-511.

Kunimoto D, Brunham R C 1985 Human immune response and Chlamydia trachomatis infection. Reviews of Infectious Diseases 7:665-673.

Kuo C-C 1978 Cultures of Chlamydia trachomatis in mouse peritoneal macrophages : factors affecting organism growth. Infection and Immunity 20:439-445.

Manor E, Sarov I 1986 Fate of Chlamydia trachomatis in human monocytes and monocyte-derived macrophages. Infection and Immunity 54:90-95.

Martin D H et al. 1982 Prematurity and perinatal mortality in pregnancies complicated by maternal Chlamydia trachomatis infections. Journal of the American Medical Association 247:1585-1588.

McLaren A, Michie D 1959 Superpregnancy in the mouse. 1. Implantation and foetal mortality after induced superovulation in females of various ages. Journal of Experimental Biology $36: 281-300$.

Munday P E et al. 1984 Spontaneous abortion-an infectious which fetal injury was most likely to occur should there be transplacental passage of organisms. As chlamydiae were still present in the placentas on day 18 of gestation, it is unlikely that systemic infection after placentation would be any more deleterious to the fetus. However, experiments are being done to resolve this question. Because both mouse and man have advanced haemochorial placentas in which the trophoblast is bathed directly by circulating maternal cells, the mouse model that enables fetal development in utero to be studied in the presence of chlamydial infection has much to offer in relation to the problem of chlamydial infection in man.

aetiology? British Journal of Obstetrics and Gynaecology 91: $1177-1180$

Rodolakis A 1983 In vitro and in vivo properties of chemically induced temperature-sensitive mutants of Chlamydia psittaci var. ovis: screening in a murine model. Infection and Immunity 42:525-530.

Rothermel C D 1985 Chlamydia and human monocytes; relationship between parasite growth and host cell differentiation. Abstracts of the Annual Meeting of the American Society of Microbiology, p. 30.

Schachter J 1967 Isolation of Bedsoniae from human arthritis and abortion tissues. American Journal of Ophthalmology 63 Suppl: 1082-1086.

Storz J 1971 Chlamydia and chlamydia induced diseases. Charles $C$ Thomas, Springfield, Illinois.

Thomas B J, Evans R T, Hutchinson G R, Taylor-Robinson D 1977 Early detection of chlamydial inclusions combining the use of cycloheximide-treated McCoy cells and immunofluorescence staining. Journal of Clinical Microbiology 6:285-292.

Thomas B J, Reeve P, Oriel J D 1976 Simple serological test for antibodies to Chlamydia trachomatis. Journal. of Clinical Microbiology 4:6-10.

Tuffrey M, Falder P, Gale J, Taylor-Robinson D 1986 Salpingitis in mice induced by human strains of Chlamydia trachomatis. British Journal of Experimental Pathology 67:605-616.

Tuffrey M, Falder P, Thomas B, Taylor-Robinson D 1984 The distribution and effect of Chlamydia trachomatis in CBA mice inoculated genitally, intra-articularly or intravenously. Medical Microbiology and Immunology 173:29-35.

Tuffrey M, Taylor-Robinson D 1981 Progesterone as a key factor in the development of a mouse model for genital-tract infection with Chlamydia trachomatis. FEMS Microbiology Letters 12: 111-115.

Wong S Y, Gray E S, Buxton D, Finlayson J, Johnson F W A 1985 Acute placentitis and spontaneous abortion caused by Chlamydia psittaci of sheep origin: a histological and ultrastructural study. Journal of Clinical Pathology 38: 707711 . 